両側大腿骨頭及び両側上腕骨頭に 発生せる特発性壊死の 1 例

\author{
熊本市民病院整形外科 \\ 広田 耕 三・林泰 夫 \\ 武田幸之助・堀川広通
}

\title{
A Case Report of Idiopathic Aseptic Necrosis of Bilateral Femoral Heads and Humeral Heads.
}

\author{
by \\ K. Hirota, Y. Hayashi, K. Takeda \& H. Horikawa \\ Kumamoto Municipal Hospital
}

\begin{abstract}
One case, male, 37 years old, suffering from pain and restriction of joint motion of bilateral hips and shoulders was reported. Roentgenograms of bilateral hips showed marked deformity of the femoral heads due to destruction of the subchondral bone matrix. Intraosseous venography showed marked retardation of venous return. Total hip replacement (W-Huggler type) was performed on the right hip with success. Left hip will be treated with W.-Huggler total hip replacement. In microscopic observation of the excised femoral head, osteoblasts, osteoclasts and foreign body giant cells were observed. The intima of arterioles in the joint capsule showed peculiar thickening, differing from atherosclerosis.
\end{abstract}

近年，大腿骨頭特発性壊死が注目され，その病因， 病理, 臨林わよび治療の研究報告が相次いでいる.わ れわれは, 最近, 両側上腕骨頭と両側大腿骨頭に特発 性壊死をきたした 1 症例を経験したので報告する.

症例は 37 才の男子, 新聞販売店主.

既往歴，家族歴，職業歴に特記すべきものなく，ス テロイド剤使用歴もない。

嘹好として, 酒は平均 1 日 $4 \sim 5$ 合, 煙草は 1 日約 50 本で, かなりの愛酒, 愛煙家である.

現病歴：約 2 年前より, 野球等の運動後に両腎部に だるい疲労感を自覚したてとあり．約 1 年前より両股 関節の外転制限, 歩行時痛を自覚するようになり, 徐 々に増悪して右股関節の内転位拘縮と著明な跛行を呈 するようになってきた. また， 1 年前より両肩に軽度 の運動制限を訴え, 徐々に増強の兆あり. 外傷の記憶 はない。

現症：全身所見：身長 $163.5 \mathrm{~cm}$. 体重 $47 \mathrm{~kg}$. 食 欲, 睡眠良好. 便秘がち ( $2 \sim 3$ 日に一行), 血圧 $120 \sim 80 \mathrm{mmHg}$, 胸部打聴診上著変なく, 胸部 X線所 見, 心電図ともに著変なし. 臨床検査成績（表1）に

\section{表 1 臨床検查成績}

血 液 検 査: $\mathrm{Hb}$. $88 \%$. Ht. $39 \%$. 赤血球数 426 万白血球数 5,900 . 末梢血液 像に著变なし.

肝機能㭘查: G.O.T. 14.5 Karmen 単位 G. P.T. 9.5 " $"$ " T.T.T. 3.5 Kunkel "

血清蛋白検查: 総蛋白 $7.4 \mathrm{~g} / \mathrm{dl} \mathrm{A} / \mathrm{G}$ 比 1.56

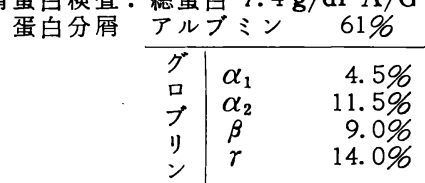

R.A.テスト陰性. C.R.P. 陰性. 血沈值平 均 $1 \mathrm{~mm}$. 血清梅毒反応陰性. L.D. H. 80 Wacker 単位. $\begin{array}{ll}\text { アルカリ・フォスファターゼ } & 9.5 \mathrm{~K} . \mathrm{A} . \text { 単位 } \\ \text { 酸フォスフォターゼ } & 2.4 \mathrm{\prime \prime}\end{array}$

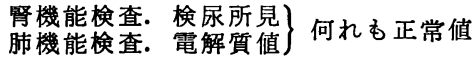

\section{も著変を認めない。}

局所所見: 両股関節部に腫脹, 発赤, 局所熱なし. 大腿骨頭の軽度の圧痛と大転子によりの吒打痛あり. 運動制限（屈曲右 $60^{\circ}$, 左 $70^{\circ}$, 伸展右 $15^{\circ}$, 左 $10^{\circ}$, 外転右 $-10^{\circ}$, 左 $+10^{\circ}$, 内旋右 $15^{\circ}$, 左 $10^{\circ}$, 外旋 
右 $20^{\circ}$, 左 $20^{\circ}$ ) と運動痛あり. 右股関節の内転位拘 縮と股痛のため跛行著明.下肢長差なし。両局関節： 軽度の運動制限（側举 $90^{\circ}$, 前挙 $140^{\circ}$, 内外旋正常) あり，運動痛，圧痛が軽度にあるが，ADLにはとん ど支障なし。

X線所見（図 1)：両側大腿骨頭は高度の壊死圧潰 像を呈する，右側は関節裂隙は全く消失し，寛曰にも 骨吸收が見られる，左側は関節裂隙る保たれ，寛臼は 正常である.

両肩関節（図2）は，上腕骨頭に示指頭大の壊死像 を漶めるが, 骨頭の変形や, 関節裂隙の狭少変化は見 られない、日整会三次案による股関節評価点数は 53 点であつた（表 2).

経骨璡静脈造影所見（図 3 ) : 右大腿骨頭にウログ ラフィン $10 \mathrm{cc}$ を注入するに，抵抗が強く，珐入す るにつれて造影剤の関節腔への漏出を見たが, 注入 2 分後も静脈への還流はほとんど見られず，完全な阻血 状態と判断された。なお, 約 3 時間後の X 線浙見で は, 造影剤の残留はなく, 関節液を介して吸収された ものと推察される. 右大腿骨頸部では, ウログラフィ

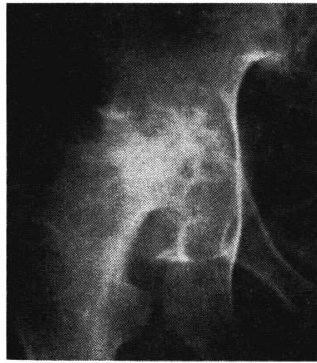

（右）

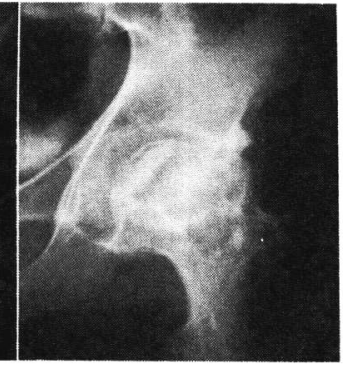

(左)
図 1

両側大腿骨頭に高度の買死を認む. 殊に, 右側は 骨頭の圧潰著明で, 関節裂腺消失し, 寞臼にも骨 吸收像を認を。

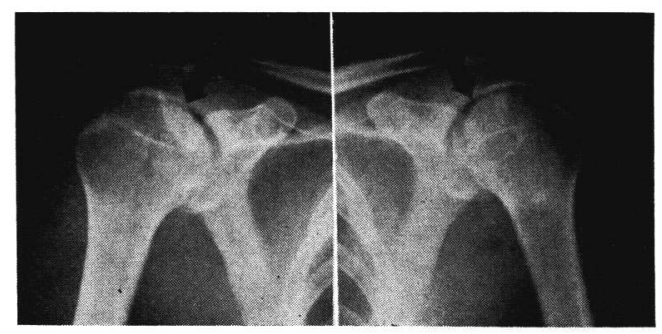

図 2

両側上腕骨頭内側に示指頭大の壊死像を認める.
ンの圧入に抵抗はあまりなく，注入開始後約 5 秒より 静脈への還流が見られ，約 1 分 30 秒でほとんど完全 に流出完了し，血流障害はないものと判断された．

治療：右股関節に対して，内転位拘縮をとるための 内転筋切離術と, Weber-Huggler 型全人工股関節 置換術を行った（図 4)。術後経過は順調で, 右股関 節には疼痛, 運動痛なく, 運動制限も改善されたが, 左股関節が未治療なので軽度の歩行痛と跛行がある. 左股関節は約 6 力月後に Weber-Huggler 型全人工 股関節置換術の予定である. なお, 術後 3 カ月での股

表 2 股関節機能評価（日整会 3 次案）

\begin{tabular}{|c|c|c|c|c|c|}
\hline \multicolumn{2}{|r|}{ 評 価 項 目 } & \multicolumn{2}{|c|}{ 術＼cjkstart前 } & \multicolumn{2}{|c|}{ 術後 3 ケ月 } \\
\hline 疼 痛 & 歩行痛 & 中等度 & 20 点 & 軽 度 & 30 点 \\
\hline 可動性 & $\begin{array}{ll}\text { 屈 } & \text { 曲 } \\
\text { 外 }\end{array}$ & $\begin{array}{r}65^{\circ} \\
-10^{\circ}\end{array}$ & $\begin{array}{l}9 \\
0\end{array}$ & $\begin{array}{r}100^{\circ} \\
15^{\circ}\end{array}$ & $\begin{array}{r}12 \\
4\end{array}$ \\
\hline 歩 行 & 跛 行 & 著明 & 10 & 軽 度 & 15 \\
\hline A D L & $\begin{array}{l}\text { 腰かけ, 正坐, 坐礼 } \\
\text { ゃがみ, 立ち上り } \\
\text { 靴下着脱, 足爪切り } \\
\text { 患脚立ち } \\
\text { 階段の昇降 }\end{array}$ & $\begin{array}{l}\text { 容易 } \\
\text { 困難 } \\
\text { 困難 } \\
\text { 容易 } \\
\text { 困難 }\end{array}$ & $\begin{array}{l}6 \\
2 \\
2 \\
2 \\
2\end{array}$ & \begin{tabular}{|cc} 
容 & 易 \\
やや困難 \\
容 & 易 \\
容 & 易 \\
やや困難
\end{tabular} & $\begin{array}{l}6 \\
3 \\
4 \\
2 \\
3\end{array}$ \\
\hline & 忩 合 点 数 & & 53点 & & 79点 \\
\hline
\end{tabular}

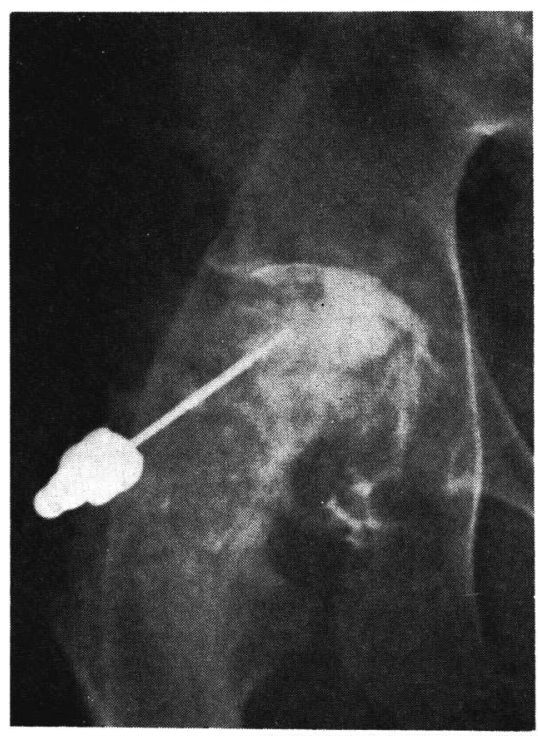

図 3

右大腿骨頭経骨䯣静脈造影，造影剂の関節腔 への漏出あり, 注入 2 分後も, 静脈への流出 を見ない。 


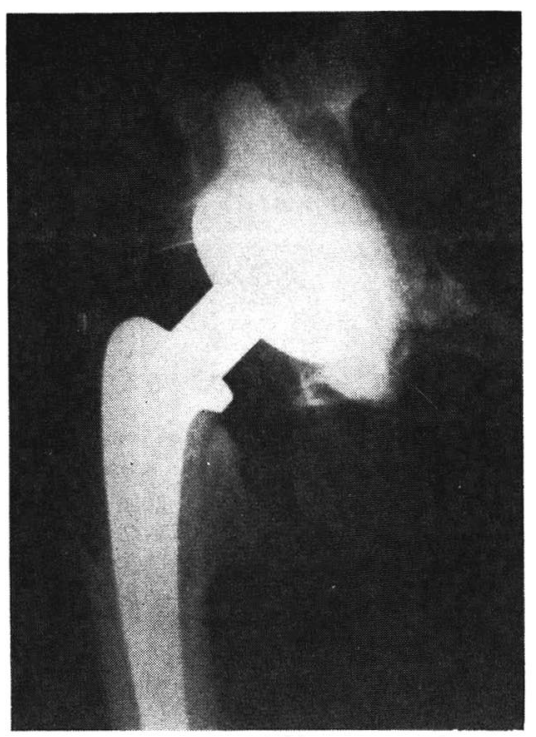

図 4

右股に, W.-Huggler 型 T.H.R.

関節評価点数（日整会 3 次案による）は 79 点で, 術 前の 53 点からかなり 改善されており，患者は非常に 満足し，左股関節の手術を希望している．両肩関節 は，現在の症状が軽度で，A D Lにもあまり支障がな いので，当分は経過観祭の予定である.

摘出骨頭所見（図 5 ）：関節軟骨は比較的よく温存 されているが, 軟骨下骨組織は著しい破壊, 壊死を来 して Cyst 状となり，このため骨頭は圧漬されて著し い変形を起し，関節軟骨面にも揮裂破綻を生じてい る.

組織標本所見：関節軟骨組織は比較的よく温存され ていて，一部には軟骨細胞の増生も見られた．軟骨下 骨組織は破壊吸収が省明で, 骨組織に近く破骨細胞や 造骨細胞および異物巨細胞が見られた。また，健常部 との境界部分には線維芽細胞の増生が見られた。

注目すべき所見として, 関節包の小動脈に内膜の特 異な舥厚を認めた（図6）. 内膜は全周に亘り著明に 肥厚して和管内腔を著しく狭くしている．乙の内膜肥 厚の状態は, 通常の動脈硬化症の血管に見られる部分 的内膜肥厚と異って, 全周に亘るものである.また, 肥厚せる内膜の表面に Sudanophylic なコレステロ 一ル沈着物質を有する, いわゆる, かゆ状硬化像 Atherosclerosis の所見も見られなかつた。

との特異な内膜肥厚が, 本症の病因と何らかの関連

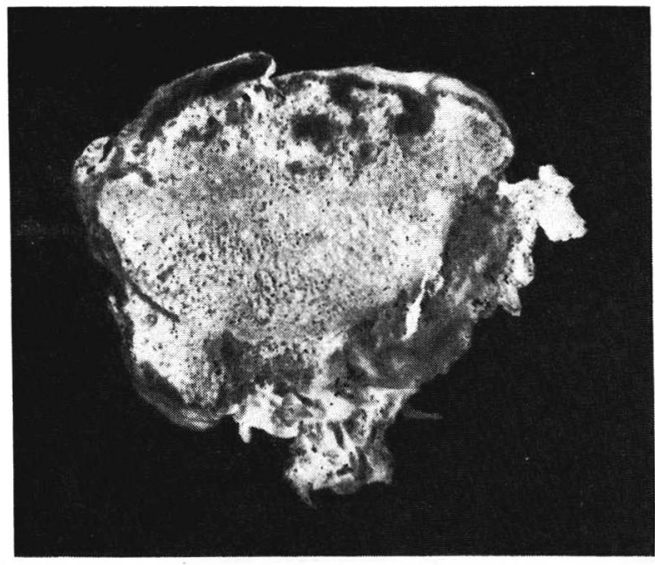

図 5 剔出骨頭割面

関節軟骨は比較的よく温存されているが, 軟骨下 骨組織が破壊されて Cyst 状となり, 圧潰された 軟骨面に揮裂を生生じている.

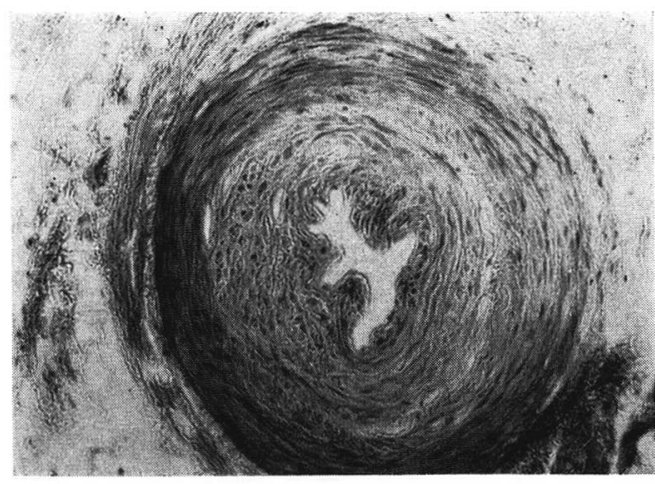

図6 関節包に見られた小動脈 内膜は全周にわたって著しく肥厚して， 血管内腔を狭めている。

を有するかは興味ある問題と思われる. 後日, 左側股 関節手術の際の組織所見, ととに, 肩関節の手術機会 があれば, 肩関節部の組織所見で同様の内膜肥厚があ るか否かを注意して検してみたい.

\section{治療に関する考察}

大腿骨頭の 病変が軽度で 壊死範囲の小さいもので は, 大腿骨頭を切除するととなく, 骨頭の荷重面の変 更と血流の改善を目的として, 種々の骨切り術が夫 されており，また，壊死部に対する搔把骨移植，骨釘 移植も試みられている。しかし，本症例のごとく，壊 死が広汎で関節軟骨の破壊を招来するに到つたもので 
は, 骨切り術や骨移植等の骨頭保存的手術法はすでに 適応を失ったものと判断される。

てれ等の重度な骨頭壊死に対しては，懐死骨頭を切 除して 全人工股関節置換術や人工骨頭置換術および Cup Arthroplasty が適応となる。 また，特発性骨 頭壊死は発症年令が 40 才乃至 50 才代に多く，しかも 約 $50 \%$ \%゙ 両側性である点から手術術式の撰択には慎 重な配慮を要する，両側性股関節症に対して，両側に 全人工股関節置換術を行うか，または，1側を全置換 として他側は股関節固定術を行うかについては論議の あるところである．渡辺等は両側股関節症において 1 側に固定術, 反対側に全置換術を行うことは, 非固定 側すなわち人工関節に，静止時も運動時も大きな負荷 を強いる結果となり，人工関節の摩粍や Loosening を早期に招きかねないので好ましくないと指摘してい る. この点より, 渡辺等は両側股関節症には両側人工 関節置換術か，または，1 側人工関節で他側に Cup Arthroplasty かの何れかを選ぶととをすすめてい る. しかし, 特発性大腿骨頭壊死では, 壊死病変はし ばしば寛白側にも影響をおよぼしているてとがあり， Cup Arthroplasty や単純人工骨頭では，早期に寛 曰の Migration を起すととが考えられるので，われ われは，本症例には両側に全人工股関節置換術を行う ことにした。

人工関節の型の撰択について : Weber-Huggler 型 の人工関節は Metal Cup と H.D.P. 骨頭と Metal Stem とから成り，骨頭は Stem 先端の軸の周りで 回転するようになっており，Rotation Prosthese と 称されている.すなわち股関節の運動は Cup と骨頭 との間の球面運動，および，骨頭と Stem .上端の軸 との間の回転運動（股関節の届伸運動のかなりの部分 を占める）との 2 力所の運動に分散され，しかも，そ の各々が Metal to H.D.P. で構成されているので, 各部の摩籷は比較的小さいのではないかと考えられ る.また, 骨頭ボールの中心には小孔があり, 関節液 が流通するので骨頭は Cup と Stem の間で, 恰も, Floating Cup Arthroplasty のごとき形をとり, 運 動に際してポンプ効果を呈し，運動を一凰潤滑にする とされている。また, 摩籷が起るのは Metal 亿挾ま れた H.D.P.の骨頭ボールと考えられるが，将来，
摩籷による再手術に際しては，Cup やStem を扱う ことなく骨頭のみを取り換えるだけで済むという利点 もある。

以上の理由から，われわれは，本症例に対して両側 股関節に Weber-Huggler 型全人工股関節置換術を 行うととに決定した。

\section{ま と め}

37 才の男子に 発生せる両側大腿骨および 両側上腕 骨の特発性骨頭壞死を報告した。両側大腿骨頭壊死の 報告は多く見られるが，特記すべき職業歴（潜水夫な ぞ）なく両側上腕骨頭にも特発性壊死をきたした例は まれと考える．本症例のごとく両側大腿骨頭に高度の 壊死圧潰をきたした場合の治療について考察を加えた ・また，組織所見で，小血管の内膜に特異な肥厚を認 めたが，てれは，通常の動脈硬化症に見られる内膜肥 厚と所見を異にしており興味を覚えた。

謝辞

御指導, 御稿閲を頂いた態本大学整形外科玉井達二 教授，および，組織学的検查を担当して頂いた本院臨 床検査科部長松本英世博士に深く感謝します。

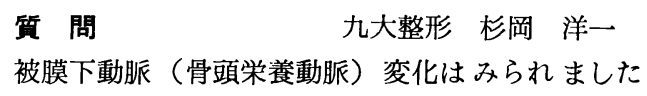
功.

解 答熊本市民病院 広田 耕三 小血管の内膜肥厚像は関節包に 見られたものであ る. 関節包の骨盤側と大腿骨側の何れにも見られた が，これが骨頭栄養血管であるか否かは明確でない。

\section{引用 文 献}

1）泉類博明 他：臨整外. 8巻, 816頁, 1973.

2）梅原忠雄 他: 整外. 22巻, 450頁, 1971.

3）大塩訓喜 他：臨整外. 6巻, 500頁, 1971 .

4）川島真人 他: 嚂整外. 8巻, 933頁, 1973.

5）河路 渡：整外. 20巻, 372面, 1969.

6）長谷川愫：日整会誌. 45巻, 441頁, 1971 .

7）渡辺 良他：臨整外. 8巻, 347頁, 1973.

8）渡辺良他：臨整外。 8巻, 944頁, 1973. 